\section{Response to: 'Correspondence on 'Ultrasound shows rapid reduction of crystal depositions during a treat-to-target approach in gout patients: 12-month results from the NOR-Gout study" by Hung et al}

We appreciate the interest by Hung et $\mathrm{al}^{1}$ in our article describing the rapid reduction of ultrasound-detected crystal depositions in gout during 12 months of treat-to-target follow-up on uratelowering treatment (ULT).

Hung et al comment on the lack of control group in our study, and they suggest a double-blind, controlled study to explore the effectiveness of ULT, and they comment on the lack of information regarding blindness of operators and participants. ${ }^{1} \mathrm{We}$ certainly agree on a randomised controlled trial (RCT) being necessary to confirm our findings, which are based on an observational study without a control group, where neither sonographers nor patients were blind to the treatment. However, since in addition to our study, several smaller studies have shown the reduction of urate depositions during $\mathrm{ULT}^{2-6}$ and given the strong recommendations to reduce serum urate levels in gout to a target, ${ }^{78}$ a long-lasting RCT with a control group not treated according to current guidelines, at least in Scandinavia, seems not ethically acceptable to patients.

In our study, we did not have focus on the different uratelowering drugs applied but rather on whether patients achieved the treatment target of $<6 \mathrm{mg} / \mathrm{dL}$. In addition, all our patients were treated with either allopurinol or febuxostat, and none of the patients used probenecid or benzbromarone. The group of patients with tophi had a more ambitious treatment target of $<5 \mathrm{mg} / \mathrm{dL}$ but accounted for less than $20 \%$ of patients, making meaningful conclusions in this cohort difficult.

There is no agreement on how many joints and tendons to examine by ultrasound when the load of depositions of crystals is assessed. We agree that additional joints and tendons could be explored with ultrasound, giving a more comprehensive examination of regions reported to be potential locations for depositions. We have, however, examined many joints, tendons and entheses, determined after careful literature research as well as discussions with experts in the field. A larger array of localisations would not be feasible in clinical practice as in our study but may be useful in other research settings.

The suggestion of including erosions as an outcome measure is relevant. Our study describes erosions of the medial part of the first metatarsal head to be present in about $60 \%$ of the patients. However, as could be expected, there was no change of the score of these erosions during the study. Thus, even if description of erosions is of interest to indicate the severity of the disease, it may not be appropriate as an outcome for treatment response.

Our study was performed at the Department of Rheumatology at Diakonhjemmet Hospital, Oslo, Norway, with inclusion between 2015 and 2018. The paper describes most of the inclusion criteria, and important exclusion criteria were severe comorbidity, including heart failure (New York Heart Association III-IV) or kidney failure (eGFR $<45 \mathrm{~mL} / \mathrm{min}$, chronic kidney disease stage $3 \mathrm{~B}$ ). We thank for the interest in our study and will provide more clinical results from our study in future publications, including detailed information about treatment, clinical assessments and outcomes.

Hilde Berner Hammer $\odot{ }^{1,2}$ Lars Fridtjof Karoliussen, ${ }^{1}$ Lene Terslev $\odot{ }^{3}$ Espen A Haavardsholm, ${ }^{1,2}$ Tore K Kvien, ${ }^{1,2}$ Till Uhlig ${ }^{1,2}$
${ }^{1}$ Department of Rheumatology, Diakonhjemmet Hospital, Oslo, Norway 2University of Oslo, Faculty of Medicine, Oslo, Oslo, Norway

${ }^{3}$ Centre for Rheumatology and Spinal Diseases, Glostrup, Rigshospitalet, Copenhagen, Denmark

Correspondence to Dr Hilde Berner Hammer, Rheumatology, Diakonhjemmet Sykehus, 0370 Oslo, Norway; hbham@online.no

Handling editor Josef $S$ Smolen

Collaborators Not applicable.

Contributors HBH has written the draft and finalised the present comments to Hung et al. LK, LT, EAH, TKK and TU have all revised the manuscript critically for important intellectual content and given a final approval of the version to be published.

Funding The authors have not declared a specific grant for this research from any funding agency in the public, commercial or not-for-profit sectors.

Competing interests Dr Hammer reports personal fees from AbbVie, Lilly and Novartis, outside the submitted work. Dr Karoliussen has nothing to disclose. Dr Terslev reports personal fees from Novartis, Roche, BMS and Pfizer outside the submitted work. Dr Haavardsholm reports personal fees from Pfizer, UCB, Eli Lilly, Celgene, Janssen-Cilag, AbbVie and Gilead outside the submitted work. Dr Kvien reports grants and personal fees from AbbVie, MSD, UCB, Hospira/Pfizer, Eli Lilly, grants from BMS, personal fees from Roche, Hikma, Orion, Sanofi, Celltrion, Sandoz, Biogen, Amgen, Egis, Ewopharma and Mylan, outside the submitted work. Dr Uhlig reports personal fees from Grünenthal and Novartis, outside the submitted work.

Patient and public involvement Patients and/or the public were not involved in the design, or conduct, or reporting, or dissemination plans of this research.

Patient consent for publication Not required.

Provenance and peer review Commissioned; internally peer reviewed. (c) Author(s) (or their employer(s)) 2020. No commercial re-use. See rights and permissions. Published by BMJ.

\section{Check for updates}

To cite Hammer HB, Karoliussen LF, Terslev L, et al. Ann Rheum Dis Epub ahead of print: [please include Day Month Year]. doi:10.1136/annrheumdis-2020-218908

Received 1 September 2020

Accepted 3 September 2020

\section{G Linked}

- http://dx.doi.org/10.1136/annrheumdis-2020-218846

Ann Rheum Dis 2020;0:1. doi:10.1136/annrheumdis-2020-218908

\section{ORCID iDs}

Hilde Berner Hammer http://orcid.org/0000-0001-7317-8991

Lene Terslev http://orcid.org/0000-0003-3690-467X

\section{REFERENCES}

1 Hung P-C, Lin D-H, Ker A, et al. Correspondence on 'Ultrasound shows rapid reduction of crystal depositions during a treat-to-target approach ingout patients: 12-month results from the NOR-Gout study'. Ann Rheum Dis 2020. doi: 10.1136/ annrheumdis-2020-218846.

2 Thiele RG, Schlesinger N. Ultrasonography shows disappearance of monosodium urate crystal deposition on hyaline cartilage after sustained normouricemia is achieved. Rheumatol Int 2010:30:495-503.

3 Ottaviani S, Gill G, Aubrun A, et al. Ultrasound in gout: a useful tool for following uratelowering therapy. Joint Bone Spine 2015;82:42-4.

4 Das S, Goswami RP, Ghosh A, et al. Temporal evolution of urate crystal deposition over articular cartilage after successful urate-lowering therapy in patients with gout: an ultrasonographic perspective. Mod Rheumatol 2017;27:518-23.

5 Peiteado D, Villalba A, Martín-Mola E, et al. Ultrasound sensitivity to changes in gout: a longitudinal study after two years of treatment. Clin Exp Rheumatol 2017;35:746-51.

6 Ebstein $\mathrm{E}$, Forien $\mathrm{M}$, Norkuviene $\mathrm{E}$, et al. Ultrasound evaluation in follow-up of uratelowering therapy in gout: the useful study. Rheumatology 2019;58:410-7.

7 Kiltz U, Smolen J, Bardin T, et al. Treat-to-target (T2T) recommendations for gout. Ann Rheum Dis 2017;76:632-8.

8 Richette P, Doherty M, Pascual E, et al. Updated European League against rheumatism evidence-based recommendations for the diagnosis of gout. Ann Rheum Dis 2018;2020:31-8. 